\author{
BOGUSŁAW SOŁTYS \\ ORCID: 0000-0002-8359-7732 \\ Uniwersytet Wrocławski \\ Instytut Prawa Cywilnego \\ Zakład Prawa Gospodarczego i Handlowego
}

\title{
FINANSOWANIE ZADAŃ PUBLICZNYCH SAMORZĄDÓW ZAUFANIA PUBLICZNEGO - REALIZACJA ZAŁOŻENIA RACJONALNEGO PRAWODAWCY CZY UTRZYMYWANIE STANU BEZPRAWNOŚCI?
}

\begin{abstract}
Abstrakt: Państwo ma niezbywalny obowiązek finansowania ze środków publicznych wszystkich zadań publicznych. Od tego obowiązku nie może zwolnić się, umożliwiając samorządom zawodów zaufania publicznego kształtowanie i pobieranie składek członkowskich związanych z przymusową przynależnością do samorządu. Mechanizm finansowania zadań publicznych ze składek członkowskich stanowi de facto formę ukrytego opodatkowania istniejącą z pominięciem konstytucyjnych gwarancji prawa daninowego. Prowadzi także do naruszenia konstytucyjnej gwarancji sprawności i rzetelności działania wszystkich instytucji publicznych, ponieważ przerzuca $\mathrm{w}$ istocie na podmioty prywatne decyzję o przeznaczeniu lub nieprzeznaczeniu określonych środków finansowych na realizację powierzonych im zadań publicznych. Zgodnie z ideą racjonalnego prawodawcy wydawanie decyzji administracyjnych czy nadzór nad należytym wykonywaniem zawodów zaufania publicznego nie powinny być uzależnione od uchwał samorządowych ustalających wysokość składek członkowskich. Naruszenie obowiązujących reguł finansowania zadań publicznych ze środków publicznych widoczne jest zwłaszcza na przykładzie samorządu radców prawnych, który od lat pomijany jest w ustawach budżetowych, mimo że jednym z ustawowo określonych źródeł finansowania zadań tego samorządu są dotacje i subwencje.
\end{abstract}

Słowa kluczowe: zadanie publiczne, samorządy zawodów zaufania publicznego, finansowanie zadań publicznych samorządów zaufania publicznego, składki członkowskie, obowiązek przynależności do samorządu zaufania publicznego

Idea racjonalnego prawodawcy jest wyrazem uznania niedoskonałości prawa oraz konieczności wyjaśniania jego treści. Można odnaleźć ją już w starożytnej paremii Ius est ars boni et aequi (prawo jest sztuką czynienia tego, co dobre i słuszne), której autorstwo przypisuje się rzymskiemu prawnikowi Celsusowi, a rozpowszechnienie Ulpianowi — za sprawą przytoczenia w Digestach 
Justyniana. Współcześnie założenie racjonalności prawodawcy stało się oznaką dogmatycznego przeświadczenia o istnieniu idealnego (fikcyjnego), to jest zupełnego, niesprzecznego i logicznie uporządkowanego systemu norm ${ }^{1}$, metodą odnalezienia intencji ustawodawcy ${ }^{2}$, fundamentalną zasadą wykładni prawa ${ }^{3}$ oraz powszechnie stosowanym wyznacznikiem reguł metodologicznych rządzących interpretacją prawniczą ${ }^{4}$. W literaturze dostrzega się też niebezkrytycznie, że koncepcja racjonalnego prawodawcy jest często wykorzystywana perswazyjnie $\mathrm{w}$ celu zniechęcenia do kwestionowania przyjmowanej interpretacji ${ }^{5}$. Jeśli więc nie służy ona wyłącznie do ukrycia decyzji prawotwórczych, w szczególności o charakterze contra legem, lecz jest jednym ze środków poznania rzeczywistej woli prawodawcy ${ }^{6}$, powinna zasługiwać na aprobatę. Celem niniejszego artykułu jest ustalenie, czy finansowanie zadań publicznych ze środków prywatnych pochodzących ze składek członkowskich samorządów zaufania publicznego jest rozwiązaniem zgodnym z ideą racjonalnego i rzeczywistego prawodawcy, czy raczej należy postrzegać je jako niedopuszczalne, a nawet bezprawne. Wskazane zagadnienie ma istotne znaczenie nie tylko z punktu widzenia praworządności, ale również zapewnienia efektywności i skuteczności realizacji zadań publicznych przez samorządy zawodów zaufania publicznego.

Samorządy zawodów zaufania publicznego zostały normatywnie określone w art. 17 ust. 1 Konstytucji Rzeczypospolitej Polskiej ${ }^{7}$ przez pryzmat powierzonych im przez ustawodawcę zadań publicznych, polegających na reprezentowaniu osób wykonujących zawody zaufania publicznego oraz sprawowaniu pieczy nad należytym wykonywaniem tych zawodów w granicach interesu publicznego i dla jego ochrony. Konstytucja RP nie rozstrzyga, czy samorządy zawodów zaufania publicznego mogą podejmować się także innych zadań, w tym również o charakterze niepublicznym, niemniej jednak nie tworzy też w tym względzie żadnego zakazu. Jeżeli więc nie pozostają one w sprzeczności z zadaniami publicznymi wskazanymi w art. 17 ust. 1 Konstytucji RP, można przyjąć dopuszczalność ich wykonywania przez samorządy zaufania publicznego na zasadach ogólnych do-

${ }^{1}$ L. Nowak, Interpretacja prawnicza. Studium z metodologii prawoznawstwa, Warszawa 1973, s. 35 n.

2 Z. Tobor, W poszukiwaniu intencji prawodawcy, Warszawa 2013, s. 40.

3 A. Kozak, Pojmowanie prawa w teorii wykładni, Wrocław 1997, s. 75 n.

${ }^{4}$ J. Kmita, Etyczny aspekt koncepcji racjonalnego prawodawcy, [w:] Szkice z teorii prawa i szczegółowych nauk prawnych, red. S. Wronkowska, M. Zieliński, Poznań 1990, s. 416 n.

5 S. Wojtczak, Wplyw konceptu ,racjonalnego prawodawcy” na polska kulture prawna, [w:] Wielowymiarowość prawa, red. J. Czapska, M. Dudek, M. Stępień, Toruń 2014, s. 99 n.

${ }^{6} \mathrm{Na}$ temat relacji między koncepcją racjonalnego prawodawcy a koncepcją rzeczywistego prawodawcy zob. A. Borowicz, Argument interpretacyjny odwołujacy się do woli rzeczywistego prawodawcy, „Studia Prawno-Ekonomiczne” 79, 2009, s. 17 n.

7 Konstytucja Rzeczypospolitej Polskiej z dnia 2 kwietnia 1997 roku (Dz.U. z 1997 r. Nr 78, poz. 483) (dalej: Konstytucja RP). 
tyczących wszystkich podmiotów ${ }^{8}$. Z przepisów Konstytucji RP wynika również, że reprezentowanie zrzeszanych osób oraz piecza nad należytym wykonywaniem przez nie zawodu zaufania publicznego nie są zadaniami własnymi samorządów zaufania publicznego, ale powierzonymi im na wyłączność. Zadania te są realizowane w interesie publicznym w celu zapewnienia odpowiedniej jakości świadczeń osób wykonujących wyróżnione konstytucyjnie zawody z uwagi na ich szczególne znaczenie dla zaspokajania potrzeb społeczeństwa i obywateli. O własnych zadaniach publicznych można zaś zasadnie mówić tylko w odniesieniu do organów władzy państwowej oraz samorządu terytorialnego w związku z decentralizacją władzy państwowej (zob. art. 166 ust. 1 i 2 w zw. z art. 15 Konstytucji RP), natomiast w przypadku przekazania zadań publicznych innym podmiotom nie stają się one ich zadaniami własnymi, nawet w razie przypisania im określonych zadań na wyłączność 9 . Samorządy zawodów zaufania publicznego, wykonując zadania publiczne, nie stają się przez to organami władzy państwowej, lecz jedynie spełniają podobne funkcje jak te organy. W związku $\mathrm{z}$ tym są nawet klasyfikowane jako forma zdecentralizowanej rzeczowo władzy publicznej będącej odpowiednikiem i namiastką władzy państwowej w sferze legislacji, egzekutywy i sądownictwa, która stoi na straży prawidłowego wykonywania zawodów zaufania publiczne$\mathrm{go}^{10}$. Samorządy zawodów zaufania publicznego nie zostały jednak wyposażone w majątek publiczny, kompetencję tworzenia prawa, państwowy przymus jego egzekwowania ani inne charakterystyczne atrybuty władzy państwowej, nie mają też udziału w dochodach publicznych ani zapewnionego finansowania wykonywanych zadań ze środków publicznych. Ustawodawca przekazał samorządom zawodów zaufania publicznego władzę publiczną tylko w takim zakresie, w jakim uznał, że jest ona niezbędna do prawidłowej realizacji powierzonych im zadań publicznych ${ }^{11}$. Zadania publiczne wykonywane przez samorządy zawodów zaufania publicznego pozostają jednak wciąż zadaniami własnymi władzy państwowej, ponieważ przekazanie tych zadań do realizacji podmiotom niepaństwowym nigdy

${ }^{8}$ W wyroku z dnia 14 grudnia 2010 roku, K 20/08 ZU OTK 2010/10A/12, Trybunał Konstytucyjny (dalej: TK) wyróżnił zadania publiczne i wewnątrzorganizacyjne samorządów zawodów zaufania publicznego, stwierdzając, że podział ten nie jest ani rozłączny, ani zupełny, co wyraźnie wskazuje na możliwość wykonywania także innych zadań.

9 Twierdzenie to znajduje oparcie w poglądach doktryny dotyczących konstrukcji prawnej zadania publicznego. Przegląd tych poglądów przedstawia M. Tabernacka, Zakres wykonywania zadań publicznych przez organy samorządów zawodowych, Wrocław 2007, s. 80 n. Por. wyrok TK z dnia 6 marca 2012 roku, K 15/08, ZU OTK 2012/3A/24.

10 Zob. na przykład wyrok NSA z dnia 23 kwietnia 1991 roku, II SA 238/91, ONSA 1992/3-4/61, oraz W.J. Wołpiuk, Zawód zaufania publicznego z perspektywy prawa konstytucyjnego, [w:] Zawody zaufania publicznego a interes publiczny — korporacyjna reglamentacja versus wolność wykonywania zawodu, Warszawa 2002, s. 19 n.

${ }^{11} \mathrm{Na}$ marginesie należy wskazać, że z punktu widzenia efektywności i skuteczności można mieć wątpliwości, czy samorządy zawodów zaufania publicznego zostały wyposażone we właściwe środki i narzędzia do realizacji powierzonych im zadań publicznych, zwłaszcza w odniesieniu do sprawowanego nadzoru. 
nie prowadzi do ich wyzbycia się. Władza państwowa kontroluje wykonywanie zadań publicznych, może je także w dalszym ciągu kształtować. Ustawodawca decyduje, jakie konkretne zadania publiczne powierzyć samorządom zawodów zaufania publicznego w celu wypełnienia dyspozycji art. 17 Konstytucji RP, same zaś samorządy nie są władne ich kreować, gdyż stanowiłoby to naruszenie zasady ich działania na podstawie i w granicach prawa (zob. art. 7 Konstytucji RP). Samorządy zawodów zaufania publicznego mają jednak zapewnioną samodzielność w realizowaniu przekazanych zadań, a władza państwowa może w nią ingerować, kontrolując i nadzorując prawidłowość ich wykonywania tylko w przypadkach określonych w ustawach. Także ustawodawca zwykły nie ma całkowitej swobody w kształtowaniu zadań samorządów zawodów zaufania publicznego, albowiem przy ich konkretyzowaniu nie powinien wykraczać poza konstytucyjnie określone ramy możliwości tworzenia tych samorządów oraz ramy innych gwarantowanych praw, wolności i konstytucyjnie chronionych zasad ${ }^{12}$. W świetle natomiast ich treści powstaje istotna wątpliwość, czy rozwiązanie polegające na finansowaniu powierzonych zadań publicznych ze środków własnych samorządów zaufania publicznego pochodzących głównie ze składek członkowskich jest wyrazem wykładni opartej na założeniu racjonalnego prawodawcy, czy raczej jest naruszeniem obowiązujących przepisów. Zasadą jest bowiem, że zadania publiczne podlegają finansowaniu ze środków publicznych. Zasada ta znajduje powszechną akceptację w literaturze ${ }^{13}$, a także w orzecznictwie Trybunału Konstytucyjnego, który państwu przypisuje niezbywalny obowiązek finansowania zadań publicznych ${ }^{14}$.

Zgodnie z art. 216 ust. 1 Konstytucji RP środki finansowe są gromadzone i wydatkowane na cele publiczne w sposób określony w ustawie. Ustawa o finansach publicznych ${ }^{15}$ regulująca powyższą materię wprawdzie nie wymienia samorządów zawodów zaufania publicznego wśród tak zwanych jednostek sektora

12 Kwestią tą w odniesieniu do pozbawienia możliwości prawidłowego sprawowania pieczy nad należytym wykonywaniem zawodu zaufania publicznego zajmował się TK między innymi w wyroku z dnia 8 listopada 2006 roku, sygn. K 30/06, ZU OTK 2006/10A/149. Trybunał stwierdził, że wprawdzie Konstytucja RP nie przesądza jednorodnego modelu zadań i kompetencji poszczególnych samorządów zawodów zaufania publicznego, pozostawiając ustawodawcy pewną swobodę w jego ukształtowaniu, jednak konieczne jest, aby prawodawca, określając ten model, zawsze zachował istotę ,pieczy” oraz wypełnił przesłankę sprawowania jej „,w interesie publicznym i dla jego ochrony".

13 Zob. na przykład B. Kucia-Guściora, Komentarz do art. 6 ustawy o finansach publicznych, [w:] Ustawa o finansach publicznych. Komentarz, red. P. Smoleń, Warszawa 2014; S. Owsiak, Finanse publiczne. Teoria i praktyka, Warszawa 1999, s. 233, oraz E. Ruśkowski, Istota, zakres i rodzaje wydatków publicznych, [w:] Finanse publiczne i prawo finansowe, red. E. Ruśkowski, C. Kosikowski, Warszawa 2010, s. 663. Por. wyrok TK dnia 6 marca 2012 roku, K 15/08, ZU OTK 2012/3A/24, oraz z dnia 14 grudnia 2010 roku, K 20/08, ZU OTK 2010/10A/129.

14 Zob. na przykład wyrok TK z dnia 13 lutego 2001 roku, K 19/99, ZU OTK 2001/2/30, oraz z dnia 8 października 2007 roku, K 20/07, ZU OTK 2007/9A/102.

15 Ustawa z dnia 27 sierpnia 2009 roku o finansach publicznych (tekst jedn. Dz.U. z 2019 r. poz. 869) (dalej: ufp). 
finansów publicznych utrzymujących się z funduszy publicznych (zob. art. 9 ufp), niemniej jednak według art. 43 ufp prawo realizacji zadań finansowanych ze środków publicznych przysługuje ogółowi podmiotów ${ }^{16}$, chyba że odrębne ustawy stanowią inaczej. Przepis ten wyraża nie tylko zasadę finansowania wszystkich zadań publicznych ze środków publicznych, ale również poprzez zawarte w nim odesłanie potwierdza, że zadania publiczne określone odrębnymi ustawami mogą być wykonywane przez niektóre podmioty na zasadzie wyłączności. Oznacza to zarówno możliwość ograniczenia prawa powszechności i równości w dostępie do finansowania zadań publicznych ze środków publicznych, jak i niedopuszczalność zlecania realizacji takich zadań publicznych, które zostały powierzone na wyłączność. Takie bowiem zadania publiczne, jak reprezentacja zawodów zaufania publicznego, piecza nad wykonywaniem tych zawodów, a także zadania z zakresu stanowienia prawa czy wymiaru sprawiedliwości, w ogóle nie mogą podlegać prawu powszechności i równości realizowania zadań publicznych ${ }^{17}$. Wydaje się zatem, że w świetle powyższych regulacji samorządom zawodów zaufania publicznego przysługuje prawo do finansowania $z$ funduszy publicznych powierzonych im zadań publicznych na zasadzie ustawowej wyłączności, a także ewentualnie innych zadań publicznych, o których powierzenie mogą się one ubiegać na zasadach ogólnych, właściwych dla wszystkich podmiotów, to jest zgodnie z zasadami uczciwej konkurencji (zob. art. 43 w zw. z art. 47 ufp).

Ustawa o finansach publicznych stanowi, że środki publiczne przeznacza się na wydatki publiczne (zob. art. 5 w zw. z art. 6 ust. 1 pkt 1 ufp). Pojęcie wydatkowania środków publicznych $w$ świetle przepisów wymienionej ustawy związane jest zarówno z określonymi podmiotami, jak i (od strony przedmiotowej) z realizacją zadań, kompetencji, funkcji i celów publicznych ${ }^{18}$. Zgodnie z art. 112 ust. 1 pkt 1 , art. 112 ust. 1 pkt 7 w zw. $z$ art. 126 oraz art. 112 ust. 2 ufp wydatki publiczne z budżetu państwa są przeznaczone między innymi na funkcjonowanie organów władzy publicznej oraz na finansowanie zadań publicznych określonych odrębnymi ustawami, w szczególności w formie tak zwanych dotacji. Jednak, mimo że samorządy zawodów zaufania publicznego uznawane są za organy władzy publicznej oraz są wyłącznym wykonawcą zadań publicznych określonych w odręb-

16 Realizacja tego prawa została uregulowana między innymi w ustawie z dnia 24 kwietnia 2003 roku o działalności pożytku publicznego i o wolontariacie (tekst jedn. Dz.U. z 2019 r. poz. 688) (dalej: uppw), ustawie z dnia 19 grudnia 2008 roku o partnerstwie publiczno-prywatnym (tekst jedn. Dz.U. z 2019 r. poz. 1445) (dalej: upp) oraz ustawie z dnia 29 stycznia 2004 roku Prawo zamówień publicznych (tekst jedn. Dz.U. z 2019 r. poz. 1843) (dalej: upzp).

17 Por. W. Misiąg, Komentarz do art. 43 ufp, [w:] Ustawa o finansach publicznych. Ustawa o odpowiedzialności za naruszenie dyscypliny finansów publicznych. Komentarz, red. W. Misiąg, Warszawa 2019.

18 Zob. C. Kosikowski, Nowa ustawa o finansach publicznych. Komentarz, Warszawa 2010, s. 67; E. Ruśkowski, op. cit., s. 663 n., oraz S. Owsiak, op. cit., s. 233. 
nych ustawach, przeważnie pomija się je w ustawach budżetowych ${ }^{19}$. W związku $\mathrm{z}$ tym faktem istotne znaczenie ma ustalenie charakteru prawnego dochodów samorządów zawodów zaufania publicznego, a zwłaszcza składek członkowskich, które stanowią ich główny dochód. Jak wynika z orzecznictwa ${ }^{20}$, do dochodów samorządów zawodów zaufania publicznego na ogół nie stosuje się właściwych dla należności publicznoprawnych przepisów kodeksu postępowania administracyjnego $^{21}$, ordynacji podatkowej ${ }^{22}$ ani przepisów o postępowaniu egzekucyjnym w administracji ${ }^{23}$ (zob. art. 60 w zw. z art. 66 i 67 ufp). Choć ustawodawca w tym względzie nie jest w pełni konsekwentny, ponieważ w większym lub mniejszym stopniu przewiduje stosowanie wskazanych przepisów do należności składkowych niektórych samorządów zawodów zaufania publicznego, na przykład do izb lekarskich $^{24}$, to jednak składki członkowskie na ogół wchodzą w skład majątku samorządów zawodowych i mają zasadniczo charakter należności prywatnoprawnych. Z uwagi na okoliczność, że składek członkowskich nie można zakwalifikować do żadnych kategorii środków wymienionych w art. 5 ufp, brak jest podstaw do uznawania ich za środki publiczne. W szczególności należy stwierdzić, że składki członkowskie nie stanowią daniny ani innej formy dochodu publicznego, do którego zalicza się wyłącznie świadczenia pieniężne ponoszone przymusowo na rzecz państwa, jednostek samorządu terytorialnego, państwowych funduszy celowych oraz innych jednostek sektora finansów publicznych (zob. art. 5 ust. 2 pkt 1 ufp) ${ }^{25}$. W konsekwencji samorządy zawodów zaufania publicznego, przeznaczając swoje dochody na realizację zadań publicznych, wyręczają państwo.

Mimo wskazanych powyżej zasad partycypacji środków publicznych fakt finansowania zadań publicznych z majątku prywatnego samorządów zawodów zaufania publicznego, a nawet całkowite przerzucenie na samorządy zaufania publicznego finansowania określonych zadań publicznych spotkały się w literaturze z aprobatą i to bez względu na wielkość angażowanych środków. Odwołując się

19 Zob. na przykład ustawę budżetową na rok 2019 z dnia 16 stycznia 2019 roku (Dz.U. z 2009 r., poz. 198), ustawę budżetową na rok 2018 z dnia 11 stycznia 2018 roku (Dz.U. z 2018 r. poz. 291), ustawę budżetową na rok 2017 z dnia 16 grudnia 2016 roku (Dz.U. z 2017 r. poz. 108) oraz ustawę budżetową na rok 2016 z dnia 25 lutego 2016 roku (Dz.U. z 2016 r. poz. 278).

20 Zob. na przykład postanowienie NSA w Warszawie z dnia 15 stycznia 1997 roku, III SA 537/96, LEX nr 32541, oraz postanowienie NSA we Wrocławiu z dnia 12 czerwca 1995 roku, SA/ Wr 1040/95, ONSA 1996/3/127.

${ }^{21}$ Ustawa z dnia 14 czerwca 1960 roku Kodeks postępowania administracyjnego (tekst jedn. Dz.U. z 2018 r. poz. 2096).

22 Ustawa z dnia 29 sierpnia 1997 roku Ordynacja podatkowa (tekst jedn. Dz.U. z 2019 r. poz. 900).

${ }^{23}$ Ustawa z dnia 17 czerwca 1966 roku o postępowaniu egzekucyjnym w administracji (tekst jedn. Dz.U. z 2019 r. poz. 1438).

${ }^{24}$ Zob. art. 116 ustawy z dnia 2 grudnia 2009 roku o izbach lekarskich (tekst jedn. Dz.U. z 2019 r. poz. 965).

25 Por. D. Antonów, Charakter prawny składki na rzecz samorząu zawodowego radców prawnych - wybrane problemy, „Radca Prawny” 2016, nr 3, s. 9 n. 
do racjonalności prawodawcy, podniesiono mianowicie, że finansowanie zadań publicznych samorządów zawodów zaufania publicznego z budżetu państwa mogłoby podważyć ich samodzielność i niezależność, a z czasem nawet przekształcić je w agendy państwowe. Dlatego stworzenie im prawnej możliwości uzyskiwania dochodów składkowych stanowi wystarczającą gwarancję zabezpieczenia finansowego realizacji powierzonych zadań publicznych ${ }^{26}$. Pogląd ten podzielił TK ${ }^{27}$, który choć zgodził się z koniecznością zapewnienia samorządom zawodów zaufania publicznego finansowania ich zadań publicznych, to jednak uznał, że może ono nastąpić nie tylko poprzez bezpośrednie zapewnienie środków publicznych na ich wykonanie w ramach budżetu państwa, ale także poprzez takie uregulowanie sytuacji prawnej podmiotu obarczonego zadaniem publicznym, aby środki finansowe były przez niego możliwe do uzyskania. Trybunał Konstytucyjny stwierdził również, że nałożone na samorząd zaufania publicznego zadania publiczne mieszczą się w kategorii ciężarów i świadczeń publicznych wymienionych w art. 84 Konstytucji RP, nawet jeśli nie są daniną publiczną w rozumieniu art. 217 Konstytucji $\mathrm{RP}^{28}$. Jednocześnie w obu powołanych wyrokach TK uznał, że ograniczenia praw i wolności samorządów zaufania publicznego są konieczne, skuteczne i proporcjonalne oraz nie są nadmierne wobec stworzenia im przez ustawodawcę możliwości pozyskiwania środków na realizację powierzonych im zadań publicznych, nie są też nadmierne w stosunku do wysokości dochodów osiąganych przez członków samorządów zawodów zaufania publicznego.

Przedstawione stanowisko nie uwzględnia wszystkich reguł prawnych związanych z finansowaniem zadań publicznych. Jego bliższa analiza prowadzi natomiast do wniosku, że jest ono raczej wyrazem błędnej wykładni utrwalającej bezprawie aniżeli efektem realizacji założenia racjonalności prawodawcy. W pierwszej kolejności należy podnieść, że na gruncie obowiązujących przepisów finansowanie zadań publicznych nie jest uwarunkowane wyłącznie posiadaniem statusu jednostki sektora finansów publicznych. Finansowanie wykonywanych zadań publicznych ze środków publicznych wcale nie musi też wiązać się z ograniczeniem samodzielności i niezależności ich dysponentów, skoro jest ustawowo dedykowane wszystkim podmiotom (zob. art. 43 ufp). Kontestowane stanowisko jest asystemowe, ponieważ $\mathrm{w}$ istocie stawia samorządy zawodów zaufania publicznego nawet w gorszej sytuacji względem ogółu podmiotów, które mogą ubiegać się o finansowanie realizacji zadań publicznych ze środków publicznych. Dotyczy to również samorządów gospodarczych, na które według ustawy nie można

26 M. Tabernacka, op. cit., s. 63 n. oraz s. 95 n.

27 Zob. zwłaszcza wyrok TK z dnia 14 grudnia 2010 roku, K 20/08, ZU OTK 2010/10A/129, dotyczący samorządu komorników. Por. odmienne wyroki TK z dnia 13 lutego 2001 roku, K 19/99, ZU OTK 2001/2/30, oraz z dnia 8 października 2007 roku, K 20/07, ZU OTK 2007/9A/102.

${ }^{28}$ Zob. wyrok TK z dnia 6 marca 2012 roku, K 15/08, ZU OTK 2012/3A/24, dotyczący samorządu notariuszy. 
nakładać obowiązku wykonywania zadań publicznych bez ich zgody ${ }^{29}$, a przecież w odróżnieniu od nich samorządy zawodów zaufania publicznego nie są władne odmówić realizacji żadnych zadań publicznych, jeśli zakresowo mieszczą się one w granicach zadań konstytucyjnie wyznaczonych (zob. art. 17 ust. 1 i por. art. 17 ust. 2 Konstytucji RP). Co więcej, dyskutowane stanowisko pomija przewidziany w Konstytucji RP oraz ufp, a także w zasadzie niekwestionowany w literaturze pogląd o obowiązku finansowania zadań publicznych ze środków publicznych, tak w ujęciu podmiotowym, jak przedmiotowym. Nie chodzi więc tylko o zapewnienie podmiotom realizującym zadania publiczne jakichkolwiek środków finansowych, lecz zdefiniowanych ustawowo środków publicznych. Państwo nie może bowiem pozwolić sobie na wykonywanie zadań publicznych w zależności od autonomicznej decyzji organów niepaństwowych o przeznaczeniu lub nieprzeznaczeniu określonych środków na realizację takich zadań, zwłaszcza wobec konstytucyjnie deklarowanego zapewnienia sprawności i rzetelności działania wszystkich instytucji publicznych (zob. preambułę Konstytucji RP). Z tej perspektywy nie powinno się pozostawiać w sferze podmiotów niepaństwowych wyłącznej decyzji o tym, czy dane zadanie publiczne zostanie sfinansowane i w jakiej wysokości, ponieważ ostatecznie to państwo odpowiada za efektywność realizacji wszystkich zadań publicznych. Dlatego wydaje się, że każde zadanie publiczne powinno być co najmniej współfinansowane ze środków publicznych w takim stopniu, aby można było urzeczywistnić konstytucyjnie gwarantowany poziom sprawności i rzetelności działania organów publicznych. Okoliczność, że państwo ponosi wydatki ze środków publicznych na finansowanie nadzoru nad realizacją zadań publicznych powierzonych samorządom zawodów zaufania publicznego, w żadnym razie nie uzasadnia twierdzenia, iż wspólfinansuje ono zadania publiczne tych samorządów, ponieważ w gruncie rzeczy nie są to te same zadania.

Usprawiedliwienia dla pozbawienia samorządów zawodów zaufania publicznego finansowania ich zadań publicznych ze środków publicznych nie stanowi również odwołanie się do konstrukcji ciężarów i świadczeń publicznych. Wprawdzie ciężary i świadczenia publiczne ponoszą zarówno samorządy zawodów zaufania publicznego, jak i ich członkowie, jednak nie są one środkami publicznymi, które przeznaczane są na realizację zadań publicznych w rozumieniu przepisów ufp. Trafnie wskazuje się w literaturze prawa finansowego ${ }^{30}$, że ciężary i świadczenia publiczne są formą obowiązkowej pomocy udzielanej przez każdego zobowiązanego ustawą $\mathrm{w}$ celu zmniejszenia zaangażowania organizacyjnego państwa i obniżenia wydatków publicznych, jednakże nie stanowią one podstawowego

29 Zgodnie z art. 5 ust. 3 ustawy z dnia 30 maja 1989 roku o izbach gospodarczych (tekst jedn. Dz.U. z 2019 r. poz. 579) samorządy gospodarcze mogą jedynie wnioskować o powierzenie im przez Radę Ministrów niektórych zadań zastrzeżonych w przepisach dla administracji państwowej.

30 T. Dębowska-Romanowska, Pojęcie podatków i innych danin publicznych w świetle konstytucji, [w:] Stanowienie i stosowanie prawa podatkowego. Księga jubileuszowa Profesora Ryszarda Mastalskiego, red. W. Miemiec, Wrocław 2009, s. 111 n. 
źródła utrzymania państwa. Ciężarów i świadczeń publicznych nie można utożsamiać z zadaniami publicznymi, które co do zasady powinny być finansowane ze środków publicznych i co najwyżej uzupełniane środkami prywatnymi. Ciężary i świadczenia publiczne od danin publicznych odróżnia nie tylko niefiskalny charakter oraz brak stałości obciążenia, ale także ich niepieniężny i niewymierny charakter, wyrażający się w określonym zachowaniu zobowiązanego, które polega między innymi na służeniu czasem, nakładem pracy, wiedzą specjalistyczną lub majątkiem osobistym. Tymczasem składki członkowskie, choć de facto są głównym źródłem finansowania zadań publicznych samorządów zawodów zaufania publicznego, mają charakter quasi-fiskalny, stały, pieniężny i wymierny, przez co w swej istocie są bardziej zbliżone do danin aniżeli ciężarów i świadczeń publicznych. Najważniejsze jednak, że nakładanie zarówno ciężarów i świadczeń publicznych, jak i danin publicznych wymaga zachowania formy ustawy (zob. art. 84 i 217 Konstytucji RP), natomiast składki członkowskie, ich wymiar, a niekiedy również ustalenie samego obowiązku ich ponoszenia ${ }^{31}$, związane są jedynie z podjęciem uchwały właściwych organów samorządów zawodów zaufania publicznego. Podobnie jak konstrukcja prawna obowiązku ponoszenia ciężarów i świadczeń publicznych oraz danin publicznych obejmuje nie tylko określenie podmiotu nim obciążonego, ale również sprecyzowanie niezbędnych elementów treści jego zachowania, tak również w przypadku składek członkowskich wydaje się, że wszystkie elementy obowiązku ich uiszczania powinny wynikać z przepisów ustawy, a nie jedynie z uchwał organów samorządów zawodów zaufania publicznego. Samorządy te nie mogą bowiem nakładać na swoich członków składek w dowolnej wysokości, która okazałaby się potrzebna do sfinansowania nakładanych zadań publicznych. Przerzucenie w całości na samorządy zawodów zaufania publicznego finansowania poszczególnych zadań publicznych w połączeniu $\mathrm{z}$ istniejącym obowiązkiem członkostwa w samorządzie stanowi de facto ukrytą formę opodatkowania naruszającą konstytucyjne gwarancje prawa daninowego (zob. art. 217 Konstytucji RP). Biorąc pod uwagę obowiązkową przynależność do samorządu (zob. na przykład art. 2 w zw. z art. 1 ust. 2 i art. 38 upa w odniesieniu do adwokatów oraz art. 40 ust. 2 urp w odniesieniu do radców prawnych), obciążenie obowiązkiem ponoszenia składek członkowskich może być również uznane za naruszenie wolności zrzeszania się (zob. art. 58 ust. 1 Konstytucji RP). Należy bowiem zauważyć, że art. 17 ust. 1 Konstytucji RP regulujący tworzenie samorządów zawodów zaufania publicznego nie przewiduje ograniczenia tej wolności (por. art. 17 ust. 2 Konstytucji RP), natomiast reglamentacja każdej konsty-

31 Dotyczy to na przykład samorządu adwokackiego (zob. art. 40 pkt 3 ustawy z dnia 26 maja 1982 roku Prawo o adwokaturze, tekst. jedn. Dz.U. z 2019 r. poz. 1513, dalej: upa) oraz samorządu radcowskiego (zob. art. 60 pkt 11 ustawy z dnia 6 lipca 1982 roku o radcach prawnych, tekst jedn. Dz.U. z 2018 r. poz. 2115, dalej: urp). 
tucyjnej wolności nie może naruszać jej istoty ${ }^{32}$ (zob. art. 31 ust. 3 Konstytucji RP), którą w przypadku wolności zrzeszania się jest wolna od przymusu swoboda członkostwa w samorządzie. Uprawnieni do wolności zrzeszania się w samorządzie zawodów zaufania publicznego nie mają bowiem żadnej alternatywy wyboru postępowania w ramach treści tej wolności ${ }^{33}$. Należy mieć przy tym również na względzie, że obowiązek przynależności do samorządów zawodów zaufania publicznego nie jest konieczny do wykonywania władzy publicznej przez te samorządy, ponieważ zapewnienie egzekwowalności decyzji każdej władzy publicznej jest możliwe i dopuszczalne w oparciu o rozwiązania ustawowe, niezależnie od jakiejkolwiek dodatkowej podległości adresatów tych decyzji. Samorządy zawodów zaufania publicznego czynności o charakterze władczym i tak wykonują wyłącznie w oparciu o wyraźne upoważnienie ustawowe, a nie podległość organizacyjną związaną ze stosunkiem członkostwa. Jako organy władzy publicznej obowiązane są bowiem działać na podstawie prawa i w jego granicach (zob. art. 7 Konstytucji RP) ${ }^{34}$.

Brak zapewnienia przez państwo finansowania zadań publicznych chociażby w części ze środków publicznych uderza w podstawy funkcjonowania samorządów zawodów zaufania publicznego jako samodzielnych, niezależnych i niepaństwowych organów zdecentralizowanej władzy publicznej i, co istotne, jedynie pomocniczych względem władzy państwowej, którym zadania publiczne zostały tylko powierzone do realizacji. Jednym z podstawowych praw tego samorządu jest własność prywatna, mająca wprawdzie charakter podporządkowany wyko-

$32 \mathrm{~W}$ orzecznictwie TK ugruntowany jest pogląd, że ograniczeń istoty konstytucyjnie określonych praw lub wolności nie mogą uzasadniać żadne względy, nawet odwołujące się wprost do przepisów Konstytucji RP (zob. na przykład wyrok TK z dnia 10 października 2000 roku, P 8/99, ZU OTK 2000/6/190).

33 Jak dotychczas kwestia konstytucyjności obowiązku zrzeszania się w samorządzie zawodu zaufania publicznego nie była przedmiotem merytorycznej oceny TK. Wprawdzie dnia 2 stycznia 2009 roku były Rzecznik Praw Obywatelskich Janusz Kochanowski wniósł wniosek o uruchomienie konstytucyjnej kontroli przepisów przewidujących obowiązek przynależności do samorządu zawodowego (RPO-598261-I/08/AK), jednak po jego śmierci postępowanie przed TK umorzono na skutek cofnięcia wniosku przez jego następcę. W kwestii oceny obowiązku przynależności do samorządu zawodu zaufania publicznego TK wypowiadał się natomiast na marginesie orzeczeń w innych sprawach, stwierdzając, że sprawowanie pieczy nad należytym wykonywaniem zawodu zaufania publicznego $\mathrm{w}$ granicach interesu publicznego i dla jego ochrony pociąga za sobą przymusowość członkostwa w takim samorządzie (zob. na przykład wyrok TK z dnia 18 października 2010 roku, K 1/09, ZU OTK 2010/8/76, oraz z dnia 18 lutego 2004 roku, P 21/02, ZU OTK 2004/2A/9).

34 Zob. na przykład wyrok Sądu Najwyższego (dalej: SN) z dnia 29 października 2009 roku, SDI 22/09, OSN SD 2009/132, oraz z dnia 6 listopada 2014 roku, SDI 32/14, http://www.sn.pl/, w których SN potwierdził, że obowiązki dotyczące szkoleń zawodowych stanowiące podstawę odpowiedzialności dyscyplinarnej mogą być nakładane tylko w ustawie, a nie w samoistnych uchwałach samorządu radców prawnych. Podobnie sądy stwierdziły niedopuszczalność uchwalania i egzekwowania przez samorząd adwokatów nieprzewidzianych w ustawie opłat wyłącznie na podstawie przepisów kompetencyjnych (zob. wyrok WSA w Warszawie z dnia 15 lutego 2007 roku, VI SA/Wa 1516/06, LEX nr 317965, oraz wyrok SN z dnia 27 września 2012 roku, SDI 25/12, LEX nr 1226772). 
nywanym zadaniom publicznym, niemniej jednak nie można ograniczyć istoty tego prawa poprzez wyłączenie zdolności jego powiększania oraz ochrony przed uszczupleniem ze strony państwa, to jest podmiotu zobowiązanego do finansowania zadań publicznych ze środków publicznych (zob. art. $64 \mathrm{w}$ zw. z art. 216 ust. 1 Konstytucji RP). Samorządy zawodów zaufania publicznego w sytuacji obciążenia ich obowiązkiem wykonywania określonego zadania publicznego właściwie mają pozorny wybór między nałożeniem na członków nowych opłat lub podwyższeniem dotychczasowych składek członkowskich a podjęciem próby pozyskania środków komercyjnych na rynku kredytowym, do czego nie są predysponowane w związku nieprowadzeniem działalności gospodarczej. Sfinansowanie nowego zadania publicznego kosztem innych powierzonych zadań publicznych nie wchodzi natomiast $\mathrm{w}$ rachubę, ponieważ $\mathrm{w}$ efekcie prowadzi do niewykonania lub nienależytego wykonania zadania. Całkowite przerzucenie na samorządy zawodów zaufania publicznego finansowania powierzonych im zadań publicznych nie może więc stanowić wypełnienia celu racjonalnego prawodawcy, który zobowiązany jest nie tyle do stworzenia warunków uzyskiwania dochodu przez samorządy, ile zapewnienia sprawnego i rzetelnego wykonywania przez nie zadań publicznych (zob. preambułę Konstytucji RP). Pozbawienie samorządów zaufania publicznego finansowania ich zadań publicznych ze środków publicznych bez wątpienia negatywnie wpływa na poziom realizacji tych zadań, jednak jest też nieproporcjonalną 35 i nadmierną ingerencją w konstytucyjnie gwarantowane prawa i wolności. $\mathrm{Na}$ gruncie Konstytucji RP warunkiem legalności reglamentacji praw i wolności jest bowiem nie tylko konieczność zaspokojenia określonego interesu publicznego, ale również skuteczność i efektywność samego ograniczenia oraz obiektywny brak możliwości zastosowania innego rozwiązania o mniejszej uciążliwości. W przypadku nałożenia na samorządy zawodów zaufania publicznego obowiązku finansowania powierzonych im zadań publicznych żadna z wymienionych wyżej przesłanek nie jest spełniona. Mając na względzie zasadę pomocniczości, zapewnienie finansowania zadań publicznych ze środków publicznych, chociażby w części gwarantującej minimalny poziom należytego ich wykonywania, z pewnością jest natomiast środkiem efektywnym i mniej ingerującym w konstytucyjne prawa i wolności. Należy mieć również na uwadze, że konstytucyjne prawa i wolności są oparte na „współdziałaniu władz”, ,współpracy partnerów społecznych”, ,własności prywatnej” i ,pomocy umacniającej uprawnienia obywateli i ich wspólnot” (por. preambułę oraz art. 20 Konstytucji RP). Niezależnie więc czy na dyskutowaną kwestię spojrzy się z perspektywy samorządu, jego członków, czy władzy państwowej, rozwiązania przerzucające w całości finansowanie zadań publicz-

${ }^{35} \mathrm{Na}$ marginesie należy wskazać, że twierdzenie, jakoby nałożenie przez ustawodawcę zadania publicznego na samorząd zawodu zaufania publicznego było proporcjonalne do dochodów członków tego samorządu, zdaje się wynikać $\mathrm{z}$ bezpodstawnego utożsamiania różnych zadań i podmiotów je realizujących. 
nych na podmioty niepaństwowe w żadnym razie nie mogą być uznane za przejaw współdziałania, współpracy, pomocy ani poszanowania własności prywatnej.

W ocenie dyskutowanego zagadnienia nie sposób pominąć również faktu, że niektóre ustawy tworzące samorządy zawodów zaufania publicznego wprost stanowią, iż jednym ze źródeł finansowania działalności samorządu są dotacje i subwencje (zob. art. 63 pkt 2 urp). Powołane unormowanie w praktyce jest jednak pustą deklaracją, ponieważ ustawy budżetowe nie wskazują samorządu radców prawnych jako beneficjenta środków budżetowych ${ }^{36}$. W literaturze odnotowuje się zaś, że samorząd ten faktycznie nigdy nie był adresatem dotacji ${ }^{37}$. Przykład samorządu radców prawnych jest więc nie tylko egzemplifikacją obowiązku państwa w zakresie finansowania zadań publicznych, ale również wymowną ilustracją naruszania tego obowiązku. Wydaje się też być potwierdzeniem rzeczywistych intencji prawodawcy odnośnie do zapewnienia efektywności realizacji zadań publicznych przez samorządy zawodów zaufania publicznego.

Podsumowując rozważania, należy skłonić się do wniosku, że dotychczasowa wykładnia przepisów prezentowana zarówno w doktrynie, jak i w orzecznictwie TK, dotycząca finansowania zadań publicznych wykonywanych przez samorządy zawodów zaufania publicznego, nie jest zgodna z ideą racjonalnego prawodawcy. Przeciwnie, w świetle systemu prawa, a w szczególności unormowań Konstytucji RP oraz ufp, państwo ma niezbywalny obowiązek finansowania ze środków publicznych wszystkich zadań publicznych, od którego nie może zwolnić się, umożliwiając samorządom zawodów zaufania publicznego kształtowanie i pobieranie składek członkowskich w związku z przymusową przynależnością do samorządu. Mechanizm finansowania zadań publicznych ze składek członkowskich stanowi de facto formę ukrytego opodatkowania istniejącą z pominięciem konstytucyjnych gwarancji prawa daninowego. Prowadzi również do naruszenia konstytucyjnej gwarancji sprawności i rzetelności działania wszystkich instytucji publicznych, ponieważ przerzuca $\mathrm{w}$ istocie na podmioty prywatne decyzję o przeznaczeniu lub nieprzeznaczeniu określonych środków finansowych na realizację powierzonych im zadań publicznych. Tymczasem, mając na względzie racjonalność prawodawczą, wydawanie decyzji administracyjnych czy nadzór nad należytym wykonywaniem zawodów zaufania publicznego nie powinny być uzależnione od uchwał samorządowych ustalających poziom wysokości składek członkowskich. Naruszenie obowiązujących reguł finansowania zadań publicznych ze środków publicznych widoczne jest zwłaszcza na przykładzie samorządu radców prawnych, który od lat pomijany jest w ustawach budżetowych, mimo że jednym z ustawowo określonych źródeł finansowania zadań tego samorządu są dotacje i subwencje.

36 Zob. przypis 19.

37 Z. Klatka, Ustawa o radcach prawnych. Komentarz, Warszawa 1999, s. 352. 


\section{FINANCING PUBLIC DUTIES OF PUBLIC TRUST ASSOCIATIONS - A REALISATION OF A RATIONAL LEGISLATOR RULE OR MAINTAINING A STATE OF LAWLESSNESS?}

\section{Summary}

The state has an inalienable duty to finance all public duties from public resources. It cannot be relieved of this duty by enabling the associations of public trust professions to constitute and collect members' subscriptions related to compulsory affiliation to the association. The mechanism of financing the public duties from members' subscriptions is de facto a form of an implicit tax existing with the omission of constitutional guarantees of tax law. This leads to violation of a constitutional guarantee of efficiency and the reliability of public institutions, since it transfers the decision to allocate or not to allocate specific funds to realise the delegated public duties to private entities. According to the idea of the rational legislator, issuing administrative decisions or supervision over the proper execution of a public trust profession should be dependent on the associations' inner acts constituting the amount of the subscription. Violation of the obligatory rules of financing the public duties from public resources is visible especially within the example of the attorney-at-law association, which for years has been omitted in the yearly budget acts, even though one of the statutory public resources meant to finance the duties of this association are subsidies and bailouts.

Keywords: public duties, associations of public trust professions, financing public duties of public trust associations, members' subscriptions, duty of affiliation to public trust association

\section{BIBLIOGRAFIA}

Antonów D., Charakter prawny składki na rzecz samorzadu zawodowego radców prawnych — wybrane problemy, „Radca Prawny” 2016, nr 3.

Borowicz A., Argument interpretacyjny odwołujacy się do woli rzeczywistego prawodawcy, „Studia Prawno-Ekonomiczne" 79, 2009.

Dębowska-Romanowska T., Pojęcie podatków i innych danin publicznych $w$ świetle konstytucji, [w:] Stanowienie i stosowanie prawa podatkowego. Księga jubileuszowa Profesora Ryszarda Mastalskiego, red. W. Miemiec, Wrocław 2009.

Klatka Z., Ustawa o radcach prawnych. Komentarz, Warszawa 1999.

Kmita J., Etyczny aspekt koncepcji racjonalnego prawodawcy, [w:] Szkice z teorii prawa i szczegótowych nauk prawnych, red. S. Wronkowska, M. Zieliński, Poznań 1990.

Kosikowski C., Nowa ustawa o finansach publicznych. Komentarz, Warszawa 2010.

Kozak A., Pojmowanie prawa w teorii wyktadni, Wrocław 1997.

Kucia-Guściora B., Komentarz do art. 6 ustawy o finansach publicznych, [w:] Ustawa o finansach publicznych. Komentarz, red. P. Smoleń, Warszawa 2014.

Misiąg W., Komentarz do art. 43 ufp, [w:] Ustawa o finansach publicznych. Ustawa o odpowiedzialności za naruszenie dyscypliny finansów publicznych. Komentarz, red. W. Misiąg, Warszawa 2019.

Nowak L., Interpretacja prawnicza. Studium z metodologii prawoznawstwa, Warszawa 1973.

Owsiak S., Finanse publiczne. Teoria i praktyka, Warszawa 1999.

Ruśkowski E., Istota, zakres i rodzaje wydatków publicznych, [w:] Finanse publiczne i prawo finansowe, red. E. Ruśkowski, C. Kosikowski, Warszawa 2010.

Tabernacka M., Zakres wykonywania zadań publicznych przez organy samorząów zawodowych, Wrocław 2007. 
Tobor Z., W poszukiwaniu intencji prawodawcy, Warszawa 2013.

Wojtczak S., Wptyw konceptu „racjonalnego prawodawcy” na polska kulture prawna, [w:] Wielowymiarowość prawa, red. J. Czapska, M. Dudek, M. Stępień, Torun 2014.

Wołpiuk W.J., Zawód zaufania publicznego z perspektywy prawa konstytucyjnego, [w:] Zawody zaufania publicznego a interes publiczny — korporacyjna reglamentacja versus wolność wykonywania zawodu, Warszawa 2002. 